\title{
The PaCT: Parents, Children and Teacher Partnership in Developing ESL Literacy
}

\author{
Madhubala Bava Harji ${ }^{1}$, Kavitha Balakrishnan ${ }^{1} \&$ Krishnanveni Letchumanan $^{1}$ \\ ${ }^{1}$ Faculty of Applied Communication, Multimedia University, Melaka, Malaysia \\ Correspondence: Kavitha Balakrishnan, Faculty of Applied Communication, Multimedia University, Melaka, \\ Malaysia. Tel: 60-126-905-718. E-mail: kavitha.balakrishnan@mmu.edu.my
}

Received: July 5, 2017 Accepted: August 13, 2017 Online Published: August 16, 2017

doi: 10.5539/elt.v10n9p150 URL: http://doi.org/10.5539/elt.v10n9p150

\begin{abstract}
Malaysia government has called for schools and parents to collaborate in nurturing the culture of reading among children, as there is no formalised programme for a more active involvement of parents in academic matters. Based on the positive results of school-home partnership of past studies, this study proposed a formalised partnership, i.e. the Smart Partnership in Reading in English (SPIRE) project. The six month project aimed to foster a partnership among the teacher, parents and children in an English storybook reading programme. It involved 25 multiracial five year old children, 25 parents and a class teacher. The parents, in partnership, with the teacher scaffold the children's reading development by reading storybooks to the children at home. Qualitative data gathered via interviews, teacher journals and home visits showed the children largely benefited from the teacher and parents collaboration. The outcome of the study was the formation of two levels of partnerships, firstly, the formation of a teacher-parent partnership, where the teacher scaffolds the parents, who in turn scaffold the children's development of reading skills at home. Secondly, the family partnership, where all family members, including extended family members were involved in scaffolding the children's reading development. This partnership also positively influenced the other children and teachers beyond the participating group. Another pertinent outcome was a clear link between the levels of partnership and the children's reading progress. The closer the parents worked with the teacher, the better was the children's reading progress. Similar partnership can also leave conventional splits in EFL context in the past and genuine sharing of responsibilities for EFL literacy development in the future.
\end{abstract}

Keywords: school-home partnership, parental involvement, ESL literacy, storybook reading programme, reading development

\section{Introduction}

The Malaysian government's attempt to address the issue of the poor reading habits and low literacy rates includes, among others, national reading campaign, i.e. read2014: One Nation Reading Together, and the Ministry of Education's new policy on remedial support, i.e. The Literacy and Numeracy Screening (LINUS) programme. The programme is aimed at identifying, screening and addressing English language literacy among primary one to primary three students to master reading (Malaysia Education Blueprint (MEB), 2013-2025). However, this objective can be only achieved if all parties, including parents work hand in hand with the Ministry. The Chairperson of the National Reading Month Committee addressing parents, mentioned, "In our quest to nurture the culture of reading, we need to start from the home ..." The Prime Minister too asserted that both parents and teachers ought to play a more active role: “... Reading should be developed as part of our culture. And in doing so, making it part of the everyday routine. The challenge now for parents and teachers is how to make that shift in attitude". Parents are constantly reminded that they "must help their children learn the art of reading". More recently, the MEB (2013-2025) too highlighted the need for schools and parents to collaborate, i.e. "to have a shared responsibility between parents and teachers to ensure quality learning for students". The Blueprint highlighted that "There is already a high level of baseline involvement among Malaysian parents. ... helping their children with their homework ... talking with their children about school ... The key now is to ensure these practices happen in every household, making families crucial partners in improving children's learning outcomes". We need to capitalise on the parents' involvement in non-academic matters. Inderjit (2014) had aptly put it, "The holy grail of reading begins at home as parents promote the reading 
skill and later into a habit for their children." What we need now is a formalised partnership, for parents and teachers to work "hand-in-hand" in addressing the above mentioned concerns.

In the light of this growing concern, the Smart Partnership in Reading in English (SPIRE) project (Madhubala et al., 2014, 2016) offers an avenue for a partnership between both the children's educators, i.e. parents as prime educators at home and teachers at school, to develop young children's early ESL literacy, particularly reading in English. It derived its insights from various reading projects and studies conducted in Britain and USA that recorded positive impact of partnership programmes. Details of the project are outlined in section 5.2 of this article.

\section{Theoretical Underpinning}

Vygotsky's $(1978,1980)$ interaction theory, which gives prominence to social interactions in learning formed the theoretical underpinning of this study. The first of the three underlying themes that unify Vygotsky's theory is the central role of a language. Vygotsky believed that language is an essential mechanism of raising the level of cognitive development. He believed that thought takes on a symbolic function, and children use the natural medium of language for representational thinking. Language is seen as a tool to interact with others and is also seen as providing children with "new tools, open[ing] up new opportunities for doing things and for organising information through the use of words as symbols" (Cameron, 2001). Second underlying theme is the importance of social interaction which is the fundamental premise of Vygotsky's work and it is here that a child's cognitive development takes place in a social context (Vygotsky, 1981). He believed that children are not empty vessels, waiting to be filled with knowledge or passively reproducing what is presented to them. The social environment, i.e. the rich, meaningful, conversational exchanges with others is seen to help shape and structure the children's world, and is an avenue for acquiring language. He believed that learning does not occur in a vacuum, i.e. child hypothesising and testing in isolation, but through social interaction, language is gained from others and internalising with the help of others to form complex thinking. The third theme is the concept of the Zone of Proximal Development (ZPD). Vygotsky $(1978 ; 1980)$ asserted that learning takes place when children are working within the ZPD:

“... the distance between the actual development level as determined by independent problem solving and the level of potential development as determined through problem solving under adult guidance or in collaboration with more capable peers ..."

Vygotsky theory, which has gained credence among educators, provides a helpful theoretical underpinning for literacy development (Morrow, 2011; Cameron, 2001). Whitehead (1990) explained:

“... A child's thinking potentially is extended greatly by partnership with an adult. It is as if the child is a head taller when working with an involved, supportive and more experienced adult. Children's reading and writing in partnership with adults are thinking at full stretch."

The need to set up a social instructional environment that provides opportunities for shared and co-operative ways of learning a language is thus essential. It is in this environment that children would internalise their social interaction with adults. Closely tied to this position and of social learning is the key idea of scaffolding, i.e. adults gradually relinquish their leadership role and gently transfer autonomy and management of the learning experience to the children. Bruner (1985) termed this shift in responsibility as the "hand over principle", which can be observed in the child's changing role, for example, over time the children begins to read to an adult.

Drawing on Vygotsky's interaction theory, the SPIRE project was conceptualised to create opportunities for social interactions through storybook reading events in school and at home, and for the teachers and parents to work hand-in-hand to scaffold the children's early English as a second language (ESL) literacy development, particularly in developing their reading skills. Figure 1 illustrates the SPIRE model (BavaHarji, Letchumanan, \& Bhar, 2014) where ESL literacy development occurs in a shared meaning experience of social interaction between the children and the adult partners (parents and/or teachers). In partnership, the adults play the role of creating an ESL environment and as coaches they scaffold the children's ESL literacy development via the physical interaction with storybooks and other ESL literacy related activities in schools and at homes. The children would internalise the social interactions within the ZPD and would ultimately be able to perform tasks, which they would otherwise not be able to perform independently. 


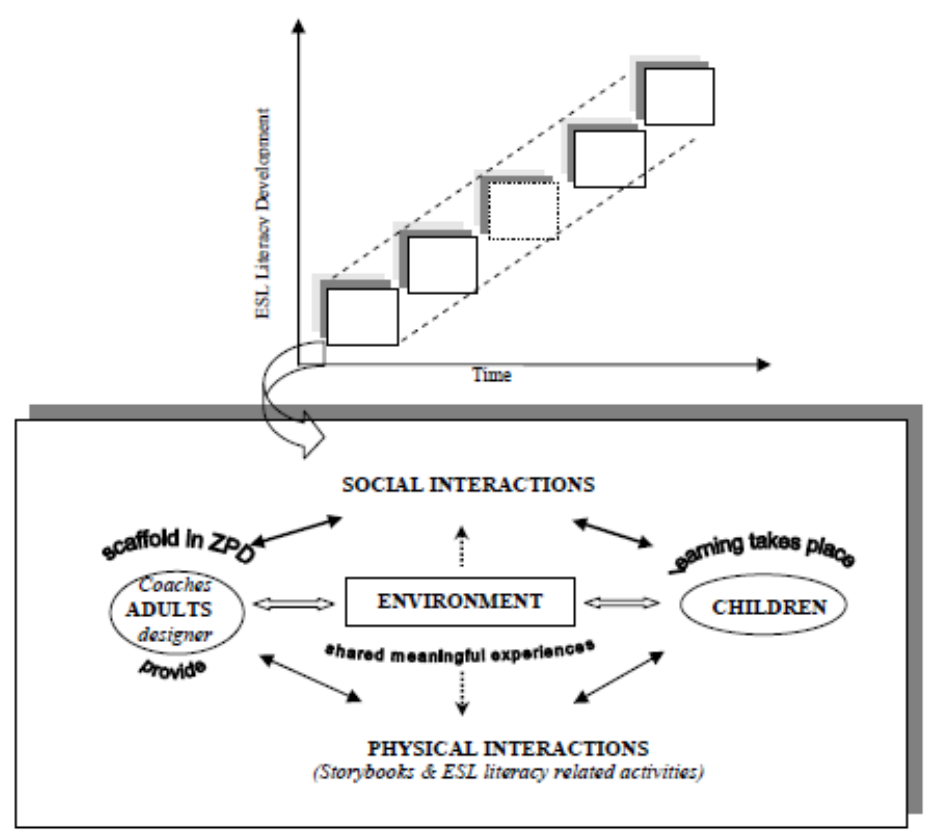

Figure 1. SPIRE model (BavaHarji, Letchumanan \& Bhar, 2014)

Within the limitation of the computer graphics, ESL literacy development in Figure 1 appears to be discrete and distinct from each other. However, in the actual contexts, a more gradual movement and overlaps in the ESL literacy development would occur.

\section{The Case for Partnership}

Since the 70s, research evidence has revealed the positive impacts of involving parents (Artley, 1975; Tizard et al., 1982; Epstein, 1983; Turner, 1987; Hannon \& Jackson, 1987; Elley, 1991; Cotton \& Wikelund, 1989; Branston \& Provis, 1999; Sénéchal \& LeFevre, 2002; Berrera \& Bauer, 2003; Barnard, 2004; Patrikakou, et al. 2005; Patrikakou, 2008; Reese, Sparks, \& Leya, 2010) and suggested "parents be made full-fledged partners in the (ESL literacy) education process" (Artley, 1975). Epstein (1986 cited in Violand-Sanshez et al., 1991) spelled out that the "challenges of education are the ones which neither families nor schools can meet alone; they must support each other. When families and schools co-operate, the children reap the benefits - they learn more, they enjoy school and the learning process, and they experience a consistent sense of commitment and support from the important adults in their lives." Hildebrand (1997: 305) concurred with "the school cannot assume the total responsibility if maximum learning is desired. It is instead the literacy of the home that determines the acquisition of school literacy". Therefore, teachers need to work hand-in-hand with parents if maximum learning is desired. Tizard, Schofield and Hewison (1982) in their Haringey project concluded that working with parents is "worthwhile". Gelfer (1991) stated the "happiest and most successful teachers are the ones who regard parents as partners and friends in the programme of educating young children".

Tompkins (2013) highlighted "literacy is a three-way partnership" among all parties involved and "schools cannot be expected to foster children's literacy alone. He asserted that parents "must become active participants" in their children's literacy development. In collaboration, both parties (instead of the child working alone) will be far better equipped to work out appropriate ways of teaching. Working in partnership along with children as educators of the children will be of better advantage for all parties concerned (Booth \& Bannister, 1991). Findings from large scale studies in Australia, UK and USA show that schools in which students do well (both academic attainment and learning attitude) are characterised by "good home-school relations" (Kelly-Laine, 1998). Leeper et al. (1984) highlighted that "If parents and teachers are going to establish partnerships that will be in the interest of children, contacts between parents and teachers should be a two-way process, from home and school and from school to home. Communication between parents and teachers is important in guiding and facilitating the child's growth and development". As partners, both parents and teacher will learn from the collaboration (Bloom, 1987; Waterland, 1988). Conserved through a mutual collaboration, they would interdependently develop the children's ESL literacy. It is time for ESL literacy revolution sparked and fuelled by collaborative efforts of parents and teachers (J. Newson \& E. Newson, 1977). 


\section{Malaysian Context}

\subsection{Malaysian Education System}

The official Malaysian education system comprises the compulsory 6 years of primary and 5 years of secondary school education, with preschool and upper secondary being optional. While preschools are mostly run by the private sectors, pre-schools in the rural areas are run by government, i.e. in selected schools. National preschools adopt the national curriculum, which is not imposed to the private sectors. Both the national language, Malay and English, the official second language are taught in all preschools to prepare the young children for formal instructions.

\subsection{Parental Involvement in Early Education in Malaysia}

Parental involvement in Malaysian pre-school appears to be rather limited as a clear line of demarcation exists between pre-schools and parents. Within the Malaysian context, the definition of involvement tends to be confined to attending Parent-Teacher Association meetings and concerts, and assisting in fund raising projects organised by schools. This entails that parents are not directly involved in developing their children's early literacy skills. Most parents indirectly support their children's development at home by equipping them with activity or story books, assisting with homework, reading and telling stories or involving in other informal and affective ways. This form of indirect involvement in children's early education is clearly an untapped resource. A study on teachers' attitudes towards parental involvement found that in-service teachers' have a positive attitude toward parental involvement (Ismail \& Abdullah, 2013).

\section{Methodology}

\subsection{Participants}

A multiracial group of 25 (10 Chinese, 8 Malays, 5 Indians, 2 Portuguese), five-years-old children, their parents, and the class teacher participated in the project. The project was carried out at a private preschool, which adopted sight vocabulary as its reading approach. Only eight children were able to recognise between 50 to 54 letters of the alphabet and a similar proportion was able to recognise less than half of the letters in the alphabet. Since most of the children spoke in their heritage (first) language, their English language proficiency was limited to one or two word level.

Except for three parents, who are graduates and four parents, who have not received any formal education, the remaining 18 parents received secondary school education. Most of them are non-professionals and middle class (average income) group. Except for the Portuguese parent, the rest of the parents generally communicate in their heritage language at home. Only four parents reported they read four or five times a week and two parents read once a week with their child. The remaining children had not encountered any storybook reading event at home.

The class teacher (Celine, pseudonym), who has been teaching in the same school for more than 18 years used textbooks and activity books as the teaching materials. Storybook reading, which was deemed "not important", was not a regular practice in class. Storybooks were read only if the teacher had time to do so to teach objects, colours or moral values. It was not embedded in the curriculum.

A project coordinator (Nina, pseudonym) was engaged to manage the project and assist with reading to the children in the Strawberry Club.

\subsection{The Smart Partnership in Reading in English (SPIRE) Project}

As the name of the project spells out, "The Smart Partnership in Reading in English" aimed to establish a smart partnership between the school and homes/teacher and parents, who are to interdependently develop the reading skills in English among the children. The project, which spanned over a period of six months, was officially launched to draw the parents into being involved in their child's ESL literacy development, namely reading development at home as well as in the project. To create a rich ESL environment at home and school, a wide range of high interest books (363 books), ranging from published series and graded books to nursery rhymes, poems and multimedia materials, were made available for the children to read in school and for them to take home weekly to read with/to their parents. A reading corner was set up in the class to replace the torn and tattered storybooks, and a Strawberry club (designated room) to house all the reading materials. The teacher read storybooks interactively, at any available time i.e. before assemblies and dismissals as well as in between lessons. Books were taken home to create opportunities for social interaction/storybook events, and for parents to scaffold and mediate the children's reading development within the ZPD. We also scaffold the parents by demonstrating the "Do's and Don'ts of storybook reading during the four meetings and individual home visits.

The teachers, parents and children signed a PACT (Appendix I), where all parties pledged their commitment. The 
teacher's commitment was in the form of making parents feel at "home", establishing a partnership and involving them in developing the children's reading skills together, communicating with them and exposing them to the routines and formats (Bruner, 1985) of effective reading techniques. The parents' committed to the partnership, in turn, to scaffold their child's reading development at home by reading interactively, regularly and repeatedly, to monitor and communicate (orally and in writing via the record cards) their child's reading progress with the teacher. The children committed to reading regularly at home, to take care of the reading materials that are taken home and to fill in the record card after each reading session.

As Kelly-Laine (1998) highlighted the need for a "good home-school relations", communication between the partners was absolutely essential for both partners to communicate with each other to assure the children that both the partners were co-operating for their benefits. The channels of communication (record cards, informal conferences, letters, newsletters, phone calls, home visits, meetings, weekend activity record) were aimed at enabling the partners to communication and evaluate the children's progress (BavaHarji, Letchumanan, \& Bhar, 2014; Harji, Balakrishnan, \& Letchumanan, 2016).

\subsection{Research Question}

This paper addresses the research question: To what extent did the SPIRE project foster partnership among the teacher, parents and children?

\subsection{Instruments}

Formal interviews with the teacher, parents and children, informal feedback during home visits and weekend activities (WA) as well as the teacher's daily entries into her teacher journal were employed to gather the teachers', parents' and children's views of the partnership.

\section{Findings and Discussion}

The qualitative data are presented as: the teacher's (Celine) entries in her teacher journal (TJ), the children's comments during the interview (example: Yasim) and the parents' feedback during the interview (example: P/Safa refers to Safa's parent) and home visits (example: HV/Ravi refers to a visit to Ravi's home). Pseudonyms are used to conceal identity and translations are given when parents spoke in broken English or the Malay language. Key words and phrases are italicised to highlight views with regards to the partnership formed throughout the project.

\subsection{Parent Teacher Partnership}

The notion of reciprocity that underpinned the partnership was apparent throughout the project. The parents' voluntary involvement, regardless of levels of involvement in their child's ESL literacy development can be viewed as evidence of mutual collaboration, support and partnership in interdependently developing the children's early reading skills. The project employed various communication channels and created a two-way form of scaffolding, i.e. from teacher to parents and vice versa. There was evidently a neutral and voluntary collaboration.

Parents favoured the partnership as it helped establish a relationship with the teacher:

... I find it useful because the relationship between the parent and teacher is important. It shows the teacher's interest in the development of the child. I think it's a great effort on your part as a teacher and [Nina] and doing this without fail ... a great effort ... (P/Gary)

... we need both sides ... good relationship ... teachers and parents because to check and balance and we both will know what problem he has ... (P/Yasim)

The project created a platform for a two-way channel of communication for sharing between partners as well as others.

... It's a two-way basis, the teacher ask parents on their opinion. At least through parents, teachers know about my son. [and] ... teacher's concern ... learning how to teach the children properly, how to read ... I find all helpful ... I try new way ... (HV/Chin Han)

$\ldots$ and we also can have discussion because what I feel is whatever idea you have, can pass it on to others ... (P/Syafa)

$$
\text { ... dapat information dan tukar pendapat ... [gain information and exchange ideas] (P/Nurul) }
$$

It was also an avenue for the teacher and parents to exchange "notes" on the children's reading developments at school and homes. Parents shared their child's reading behaviours at home: 
... She's very eager, when she gets the book, she want me to read to her. When I ask her to close the book but she will continue to hold the book and ask me to read again. ... dia suka membaca [my daughter likes to read]. semasa projek ini dia lebih menyoal [during the project, she asks more questions] ... (P/Syahina)

... His attitude towards English storybooks is good ... always reading. He's more attentive, he brings the book to me now which is a lot of difference ... and sometimes he takes a book and sits somewhere and reads silently. He says he wants to collect his own English books. He identifies his books ... (P/Ravi)

... I share with the parents during my home visits and when I meet them after school about how the children's attitude towards books has changed. ... The parents are so eager to know how their children are doing in school ... they are happy when I tell them their child is motivated to read ... always reading when they are free ... (TJ)

Some parents began to "see" their role and almost instantaneously took up their responsibility to work together with the teacher:

... yes I do follow the tips that are given ... it helps a lot ... now I know the right way to read to my son ... (P/Akhil)

... As a parent I was quite glad to participate, when it comes to reading to my child ... I know that parents too have to take part in order to see progress in our children ... (P/Gary)

... you should improve on the parents ... parent have to be the main actors ... if they don't take the interest ... no way you can [expect the child to read] ... at home, parents are important ... (P/Ravi)

The teacher, in turn, continued to encourage parents to read, share information on "good practice" for developing literacy skills and encouraged parents to read interactively to children:

... [Chin Han's] mum said that she tries her best to read to her son, but most of the time read through pictures [because she can't read in English, she's Thai in origin] ... and she says her son asks a lot of questions and this can be off-putting to her while reading storybooks ... we assure her that was a positive sign that he is paying attention to the story and to the book on the whole ... most of the time his father reads to him, but his mother always makes it a point to read to him every day. I told his mum that he can now recognise simple words and is beginning to decipher words by himself. He is also very enthusiastic about reading and this has spill over effect on the family ... (HV/Chin Han)

... As we went home visits I had a view on each method of their reading. I was able to share the different types of reading with other parents ... for example, the way [Syafa's] father encourages his daughter to read books with more words or sentences, discussing the story and asking question. I have shared this with [Farah's] mother and she was excited to try it out on her daughter ... I've demonstrated to the parents too on how to read a storybook, by pointing to the title of the book, author, illustrator and so on ... [Chee Sze's] mum demonstrated how she reads to her daughter ... some parents make story reading like a lesson ... so I share with them how other parents read to their child and they were surprised that that should be the way to read because all the time they, including [Veron's] mother thinks that it should be lesson and said that no one read to them before that is why they read that way. I encouraged them to read for pleasure ... (TJ)

The teacher had a "glimpse" of the levels of parental involvement and they scaffold their child's reading development at home:

... [Grace's] mother will try to relate stories to everyday experiences and she will also make her daughter aware of stories read that have the same story line ... (HV/Grace)

... [Farah's] mum repeates phrases and makes it a point to tell her daughter that it's the same phrases written on the other page ... that goes for the same for sentences ... (HV/Farah)

... Once when our radio was spoilt, we had to use the car radio to listen to stories ... and so all of us got into the car to listen to the taped story... (P/Syafa)

... [Veron's] mother does story reading as though it is a lesson making her daughter to spell every word that is in the storybook ... she does not stop to comment or encourage [Veron] to predict what will happen next ... her mother just wants her to finish reading the storybook ... (HV/Veron)

\subsection{Family Partnership}

Another form of partnership that emerged in this study was the mutual collaboration and support between family members and the children. The project helped create opportunities for social interactions and storybook events, i.e. for parents and children to read together, and work together on the ESL literacy related activities, which 
created a closer bond between them. We also see a reversal role of the children reading to their parents/siblings and even pets!

... I spend more time doing things with my girls and it knocks some sense to me ... I hardly spend time sitting down doing things together ... maybe we just sit down and talk and watch T.V. together ... but now we sit down together and do puppets and things ... (P/Grace)

... Yes, I tend to spend more time reading and sitting down reading with them. They have their own selection of books and they tend to read on their own. But with this project I spent more time with [Gary] and [Jim] ... (P/Gary)

... project affected my relationship with my daughter because every night I baca dengan dia [read with her] ... Membaca lebih masa dengan anak [read a longer time with my child] ... (P/Sara)

... [Ravi's] whole family will take part in the story reading because sometimes when we are busy, he will ask his brother or his maid to read to him ... (HV/Ravi)

The children confirmed the family partnership, which included pets and the "hand over principle".

... Saya di rumah ada baca, baca untuk adik, emak. Ayah balik baca untuk Yasim [I read at home, read to my younger sister and mum. Dad reads to me when he is back ...i] (Yasim)

... I will read to my younger brother and he will just sit there without moving ... He like to listen when I read to him (Christie)

... I like to read and after I finish reading, I tell the story to my fish ...I like to tell stories to my fish ... (Swee Kiong)

... I read to her cat at home ... (Sara)

Most parents reported they carried out weekend activities together with their children. The project thus helped create a structure for a partnership between parents and child, i.e. a partnership, which extended to include others/extended family members:

... It brought the family together ... even my husband ... all sat down together and cut ducks ... I've started up with the library [children as members] ... (P/Ravi)

... the family get together for reading ... (P/Chin Han)

... the whole family was involved in this assignment ... [Charlene] was very interested and excited in making the puppets ... everyone pitched in so it became a family "homework" ..." she sang the "Pussycat" song but we don't know the "Five Little Mice" song ... However, Charlene sang her own tune, which as usual made us laugh ... (WA/Charlene)

... "The Hare and the Tortoise": She knows about the story because her babysitter even told her. She helped her to do it ... (WA/Chee Sze)

... [her] cousin comes home after 7.00 p.m., she's the main person who reads to [P/Chiew Wen]

\subsection{Wider Effects of the Partnership beyond the Participating Group}

Albeit the project had aimed to foster a smart partnership among the three participating groups, i.e., parents, children and teacher, it was not envisioned that it would also affect others, i.e., the siblings, and the other teachers in the school. The siblings had "jumped onto the bandwagon on the road towards ESL literacy", exhibited interest and positive attitudes towards reading of storybooks. The other teachers in the school too had adopted storybook reading in their classes.

... Yes, I implement this project in my class ... It's very good project. Every day, I read story ... after rest time, ... the children always ask me to read to them a story, they enjoy it ... (class teacher of 6 year old children)

... some of the children who come to school early will also take a few storybooks to look at and try to read in the hall or in my class ... They too show interest in the storybooks. They come regularly to look at the storybooks ...

A partnership works when both parties are equally committed to the shared goal.

.. [Syafa's] parents are very proud of their daughter and her efforts ... they have been supportive and have faithfully given their feedback whenever they have been asked ... (HV/Syafa)

... I would like to be involved as much as possible as a parent in this project ... my boys will benefit ... I believe this project will not only benefit the students but parents as well. I would like to commend all the people 
involved in this reading project and mention my greatest appreciation ... (P/Gary)

... All the parents are very cooperative and willing to share with me when I meet them at school or at home and even anywhere when I happen to meet them ... (TJ)

The effectiveness of a partnership is indeed crucial. The teacher found that the project was "the best way of having teachers, child and parents working together in developing the children's reading ... it's very, very crucial ..." (TJ). As she commented, the children whose parents worked closely with her made better progress in the children's reading development "I have observed that parents who work together with me towards a common goal and share the responsibilities, their children are the ones who have shown lots of improvement ..." (Celine). This can obviously be seen in the varying levels of parental involvement. (Harji, Balakrishnan \& Letchumanan, 2016). The parents who took the partnership more seriously, worked closely with the teacher, participated more actively in the project and scaffold constantly their children's reading development and experienced greater progress in their child's reading ability. Of the 25 children, the 16 children whose parents worked "hand-in-hand" with the teacher made better progress at the end of the project (BavaHarji, Letchumanan \& Bhar, 2014; Harji, Balakrishnan \& Letchumanan, 2016). These parents actively scaffold their children's reading ability, attend all meetings where the teacher scaffold the parents' in designing a rich ESL literacy environment at home and read interactively to create positive social interactive during the shared reading encounters. The teacher reported their progress too:

... [Ravi] has begun to read on his own now, he is at the phase of print reading ... words that are not familiar to him, and he will ask me. He has more confidence in himself now. He seems to enjoy knowing new words ... [Akhil and Grace] are also at the stage of print reading ... they will "fly" (read very fast) through the story especially the Oxford Reading Tree books ... [Chee Sze] has also improved tremendously ... she reads independently, she is at the stage of reading print. She reads and enjoys the stories, with less support than before ... [Christie] is also at the stage of reading print, ... their attention is on print while reading, to know what the story is about rather than looking at the pictures ... (TJ)

The remaining nine children, whose parents were less/passively involved in the partnership, appeared to provide less support. They had limited storybook event encounters at home as their parents read sporadically and less interactively to them the children.

(Priya) although... slowly she started showing interest ... is more attracted to the pictures ... but will look less at the words ... she has difficulty in recognising even simple words ... even at the end of the project she will "read" to her friends and they will discuss the story that she is "reading". ... She tends to "read" the pictures more as she is at the stage of pretend reading at the end of the project ... She has made very little progress ...it is the same with the other children (James, Jeya, Jamuna, Priya, Veron, Carlene) whose parents were less involved and did not read regularly to their child ... They are non-readers .... (TJ)

A further cross examination revealed that the two Portuguese children, who speak only English at home were non-readers at the end of the project. Their parents fell into the less involved group, which provides clear evidence for the link between the levels of involvement and the effects on the children's reading development.

The teacher highlighted the effects of the partnership, which evidently and progressively nurtured the love for reading:

... Previously the children read simple words and simple sentences and ... none of the children could read even a simple storybook even though it has repeated words ... most of the children now will pass out as readers ... I am proud of the children ... and only some are non-readers ... In the second month itself, I can see different reading behaviours ... some were looking at books, pretending to read, and others reading from memory and only a few word-by-word reading and lastly conventional reading ... now the children have begun to love reading ... (I/Teacher)

Both the parents and children expressed disappointment when the project came to an end. Most parents recommended that the school adopt the project and implement it in other schools:

... He prefers English storybooks. [after the project] If he doesn't get to borrow a storybook he will keep complaining and pestering me, "Why no storybook". Keep asking me to go to school and ask the teacher for storybooks ... so that he could read more books ... (P/Swee Kiong)

I thought my daughter can continue with this project next year but it's over, what a waste ... the school should take up the project ... (P/Syafa)

... Other schools can also do this project, and they can have a partnership with the teacher just like this project 
(P/Akhil)

\section{Discussion and Conclusion}

In answer to the research question: To what extent did the project foster partnership between teachers, parents and children, it is clear that the three parties, i.e. the parents, teachers and children, and even extended family members formed partnership. It brought the two important educators, parents at home and teachers in school together for a common objective to develop the children's reading ability. We have seen that the two-way scaffolding was a form of bonding between parents and teachers, as well as other family members. The scaffolding that the parents received via meetings, home visits, record cards, letters, newsletters, etc., which adopted open communication "channels" helped the parents to scaffold their child's reading/ESL literacy. The two-way communication enabled both parties (parents and teachers) to exchange information. Consistent with the conclusions of Tizard et al. (1982), the teacher found partnership and "working with parents [was] worthwhile".

The obvious outcome of the project was the clear link between the levels of parental involvement in the partnership and the children's reading development. Parents who saw the partnership as worthwhile displayed greater levels of scaffolding of ESL literacy development, and their children reaped the most benefit as they made better progress and were independent readers at the end of the project. The frequent storybook events enabled parents and teachers to scaffold the children's reading within the ZPD, enabled the children to internalise the social interactions and eventually aided them to read independently. There was evidence of the "hand over principle", i.e. of parents relinquishing their role and handing it over to the children. The children, whose parents were less involved in the partnership, however, made slower progress as they had lesser storybook encounters and lesser parental support. In addition, the findings clearly provided evidence that the levels of involvement matters for those children whose first or heritage language is not English. Future studies would therefore need to address this and try to draw the less involved parents.

The concept of smart partnership explored in this study was clearly translated into reality in the Malaysian L2 context. The key role of active and explicit parental support and partnership role in the children's reading development has been thus far underscored in Malaysia. The positive comments made by the teacher and all parents indicate that they welcomed it. The findings of this study support the claims of other researchers (Tizard et al., 1982; Epstein, 1983; Turner, 1987; Branston \& Provis, 1986; Hannon \& Jackson, 1987; Elley, 1991) that forming partnership between the children's two prime educators in a parental involvement programme has significant gains and potentials in the children's reading development. This project clearly provides a model for a formalised/structured programme to link parents and teachers to work together for a common goal in educational activities. It also provides a means for a more structured form of parental involvement in the children's "academic" development, rather than merely on non-academic matters.

The impact of the project has created a greater sense of partnership in the children's reading development. It has also led to changes, increased knowledge and understanding of ESL literacy growth by the parents and teacher. New levels of knowledge, understanding and cooperation between the partners were established. This partnership provides evidence for the possibility of arresting the issue of poor reading habits and decline in English proficiency, especially at its roots, i.e. with young children. We have seen clear evidence of how the parents and teachers have worked together for a common goal. The project enabled the school to enlist and empower parents to take charge of their children's reading development. The partnership has clearly put the conventional spilt between homes and school in the past and a genuine sharing of responsibility for children's reading development into the future in Malaysia. This partnership provides evidence for the plausibility of unlocking ESL literacy learning and moving it from school to homes. This formalised storybook reading in English project, which found positive outcomes of involving non-native parents to play a more active role in the children's reading in English can also be adopted in EFL contexts. Similar partnership can also put conventional splits in EFL context in the past and genuine sharing of responsibilities for EFL reading development in the future. For future studies and to generalise the findings of this project nationwide, this study should be replicated and involve bigger sample of participants from public institutions.

\section{References}

Artley, A. S. (1975). Good Teachers of Reading - Who Are They? The Reading Teacher, 29(1), 26-31.

Barnard, W. M. (2004). Parent Involvement in Elementary School and Educational Attainment. Children and Youth Services Review, 26, 39-62. https://doi.org/10.1016/j.childyouth.2003.11.002

BavaHarji, M., Letchumanan, K., \& Bhar, S. K. (2014). Feasibility of building bridges between school and 
homes in developing ESL literacy: The SPIRE project. English Language Teaching, 7(9), 91-104. https://doi.org/10.5539/elt.v7n9p91

Berrera, R. B., \& Bauer, E. B. (2003). Storybook Reading and Young Bilingual Children: A Review of the Literature. In A. van Kleeck, S. A. Stahl, \& E. B. Bauer (Eds.), On Reading Books to Children: Parents and Teachers (pp. 253-67). Mahwah, NJ: Lawrence Erlbaum.

Branston, P., \& Provis, M. (1986). Children and Parents Enjoying Reading (CAPER). London: Hodder and Stoughton.

Branston, P., \& Provis, M. (1999). Children and Parents Enjoying Reading. London: David Fulton Publishers.

Bloom, W. (1987). Partnership with Parents in Reading. Sevenoaks, Kent: Hodder and Stoughton.

Booth, J., \& Bannister, I. (1991). Towards Experiences in Literacy and Language. Reading, 25(3), 15-17. https://doi.org/10.1111/j.1467-9345.1991.tb00035.x

Bruner, J. (1985). Child's talk: Learning to use language. Oxford: Oxford University Press.

Cameron, L. (2001). Teaching Languages to Young Learners. Cambridge: Cambridge University Press. https://doi.org/10.1017/CBO9780511733109

Cotton, K., \& Wikelund, K. R. (1989). Parent involvement in education, School Improvement Research Series, Close-Up No. 6, Northwest Regional Educational Laboratory. www.nwrel.org/dcpd/sirs/3/cu6.html.

Elley, W. B. (1991). Acquiring Literacy in a Second Language: The Effect of Book-Based Programs. Language Learning, 41(3), 375-411. https://doi.org/10.1111/j.1467-1770.1991.tb00611.x

Epstein, J. (1983). Effects on parents of teacher practices of parent involvement. (Report No. 346, pp. 277-294). Baltimore: The John Hopkins University.

Epstein, J. L. (1986, June). Parent involvement: Implications for limited-English-proficient parents. In C. Simich-Dudgeon (Ed.), Issues of parent involvement. Proceedings of symposium held at Trinity College, Washington, DC.

Ganapathy, M. (2016). Transformation of Malaysia's Higher Education System: Malaysia Education blueprint (2015-2025). Bulletin of Higher Education Research, 10-12.

Gelfer, J. I. (1991). Teacher-Parent Partnerships. Enhancing Communications. Childhood Education, 67, 164-167. https://doi.org/10.1080/00094056.1991.10521602

Hannon, P., \& Jackson, A. (1987). The Belfield Reading Project: Final project. London: National Children's Bureau.

Harji, M. B., Balakrishnan, K., \& Letchumanan, K. (2016). SPIRE Project: Parental Involvement in Young Children's ESL Reading Development. English Language Teaching, 9(12), 1. https://doi.org/10.5539/elt.v9n12p1

Hildebrand, V. L. (1997). Introduction to Early Childhood Education (6th ed.). New Jersey: Merrill-Prentice Hall.

Inderjit, S. (2014). Reading trends and improving reading skills among students in Malaysia. International Journal of Research in Social Sciences, 3(5). 70-81.

Ismail, A., \& Abdullah, A. G. K. (2013). Parents' Involvement in Malaysian Autonomous Schools. International Journal of Asian Social Science, 3(3), 657-668.

Kelly-Laine, K. (1998). Parents as Partners in Schooling: The Current State of Affairs. Infancy through Early Adolescence International Focus Issue, 74(4), 342-345.

Leeper, S. H., Witherspoon, R. L., \& Day, B. (1984). Good Schools for Young Children (5th ed.). New York: The Macmillan Co.

Malaysian Ministry of Education. (2012). Preliminary Report Malaysia Education Blueprint 2013-2025. Retrieved from http://www.moe.gov.my/userfiles/file/PPP/Preliminary-Blueprint-Eng.pdf

Morrow, L. M. (2011). Literacy Development in the Early Years: Helping Children Read and Write (7th ed.). Boston: Allyn \& Bacon.

Newson, J., \& Newson, E. (1977). Perspective on School at Seven-Years Old. London: George Allen and Unwin.

Patrikakou, E. N., Weissberg, R. P., Redding, S., \& Walberg, H. J. (Eds.). (2005). School-family partnerships: 
Fostering children's school success. New York: Teachers College Press.

Patrikakou, E. N., \& Anderson, A. R. (Eds.). (2005). School-family partnerships for children's success. Teachers College Press.

Patrikakou, E. N. (2008). The Power of Parent Involvement: Evidence, Ideas, and Tools for Student Success. Lincoln, IL: The Center on Innovation and Improvement. Retrieved from http://www.centerii.org/techassist/solutionfinding/resources/PowerParInvolve.pdf

Reese, E., Sparks, A., \& Leyva, D. (2010). A review of parent interventions for preschool children's language and emergent literacy. Journal of Early Childhood Literacy, 10(1), 97-117. https://doi.org/10.1177/1468798409356987

Sénéchal, M., \& LeFevre, J. A. (2002). Parental involvement in the development of children's reading skill: A five - year longitudinal study. Child development, 73(2), 445-460. https://doi.org/10.1111/1467-8624.00417

Tizard, J., Schofield, W. N., \& Hewison, J. (1982). Collaboration between teachers and parents in assisting children's reading. British Journal of Educational Psychology, 52, 1-15. https://doi.org/10.1111/j.2044-8279.1982.tb02498.x

Tompkins, G. E. (2013). Literacy for the Twenty-First Century: A Balanced Approach (6th ed.). Pearson.

Turner, R. (1987). SHARE Project - Doveton Cluster: A case study. Melbourne: Ministry of Education.

Violand-Sanchez, E., Sutton, C. P., \& Ware, H. W. (1991). Fostering Home-School Cooperation: Involving Language Minority Families as Partners in Education. NCBE Program Information Guide Series No. 6, Summer 1991. Retrieved from http://www.ncbe.gwu.edu/ncbepubs/pigs/pigs6.html.

Vygotsky, L. (1978). Interaction between learning and development. Readings on the development of children, 23(3), 34-41.

Vygotsky, L. S. (1980). Mind in society: The development of higher psychological processes. Harvard university press.

Vygotsky, L. S. (1981). The genesis of higher mental functions. In J. V. Werstch (Ed.). The concept of activity in Soviet psychology. New York: Sharpe.

Vygotsky, L. S. (1987). The Collected Works of L.S. Vygotsky. Problems of General Psychology including the Volume Thinking and Speech (N. Minick, Trans. Vol. 1). New York: Plenum.

Waterland, L. (1988). Read with Me: Apprenticeship Approach to Reading. Stroud: Thimble Press.

Whitehead, M. R. (1990). Language, Literacy in the Early Years. London: Paul Chapman Publishing. https://doi.org/10.1080/0957514900100211

\section{Copyrights}

Copyright for this article is retained by the author(s), with first publication rights granted to the journal.

This is an open-access article distributed under the terms and conditions of the Creative Commons Attribution license (http://creativecommons.org/licenses/by/4.0/). 